\title{
Teaching NeuroImages: Cerebral cortex swelling in Creutzfeldt-Jakob disease with V180I mutation
}

Atsuhiko Sugiyama, MD, PhD, Minako Beppu, MD, PhD, and Satoshi Kuwabara, MD, PhD

Neurology ${ }^{\circledR}$ 2018;91:e185-e186. doi:10.1212/WNL.0000000000005779
Correspondence

Dr. Sugiyama

chinneosyo0624@

yahoo.co.jp

Figure Brain MRI without contrast

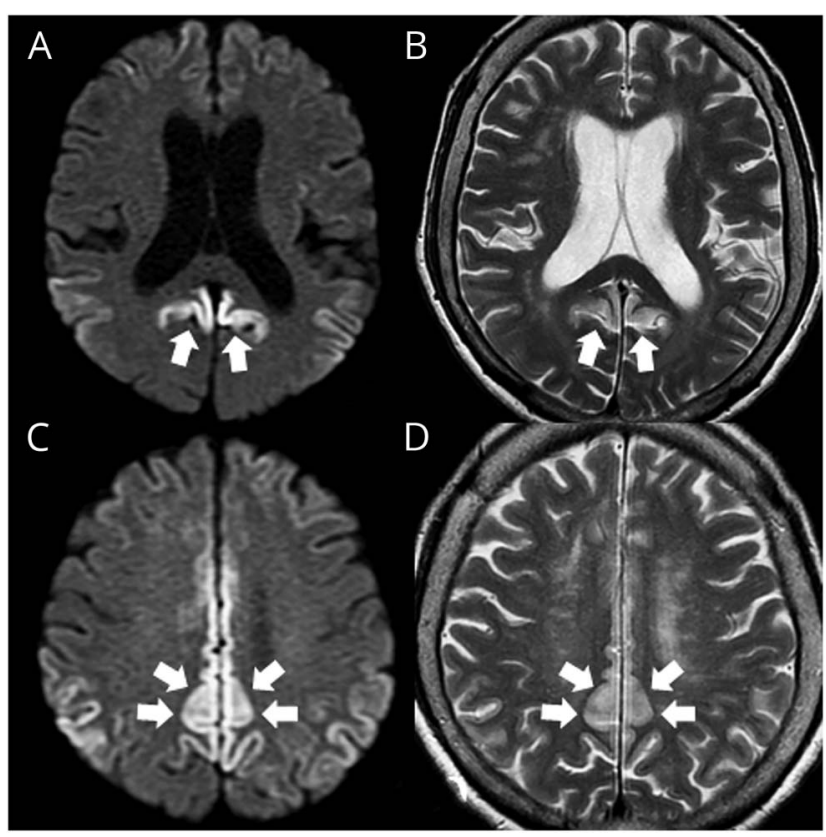

Brain MRI at 6 months after onset reveals increased signal intensity in the cerebral cortices with swelling on diffusion- weighted images (A, C) and T2-weighted images (B, D) (arrows).

A 74-year-old woman developed amnesia that rapidly progressed over 6 months. She exhibited no apparent neurologic abnormalities, except for cognitive decline. Mini-Mental State Examination score was 20/30, mainly involving orientation and recent memory. EEG revealed no periodic synchronous discharge. CSF analysis was negative for 14-3-3 protein. Brain MRI revealed abnormal signals in the cerebral cortices (cortical ribboning) with swelling (figure). Analysis of the prion protein gene (PRNP) revealed V180I mutation. Premortem diagnosis of Creutzfeldt-Jakob disease with V180I mutation, especially in early stage, merely based on clinical features is difficult. ${ }^{1,2}$ MRI revealed cortical swelling that is associated with V180I mutation and prompts genetic testing. ${ }^{1,2}$

\section{Author contributions}

Atsuhiko Sugiyama: performing patient clinical assessment, drafting the manuscript, and creating the figure. Minako Beppu: performing genetic counseling and providing assistance in patient clinical assessment. Satoshi Kuwabara: editing the manuscript.

\section{MORE ONLINE}

$\rightarrow$ Teaching slides

links.lww.com/WNL/A567

From the Department of Neurology (A.S., M.B., S.K.), Graduate School of Medicine, Chiba University; and Division of Clinical Genetics (M.B.), Chiba University Hospital, Japan. Go to Neurology.org/N for full disclosures. Funding information and disclosures deemed relevant by the authors, if any, are provided at the end of the article. 


\section{Acknowledgment}

The authors thank Katsuya Sato, Department of Molecular Microbiology and Immunology, Nagasaki University, for CSF analysis, and Tetsuyuki Kitamoto, Center for Prion Research, United Centers for Advanced Research and Translational Medicine, Tohoku University, for prion gene analysis.

\section{Study funding}

No targeted funding reported.

\section{Disclosure}

The authors report no disclosures relevant to the manuscript. Go to Neurology.org/N for full disclosures.

\section{References}

1. Jin K, Shiga Y, Shibuya S, et al. Clinical features of Creutzfeldt-Jakob disease with V180I mutation. Neurology 2004;62:502-505.

2. Iwasaki Y, Mori K, Ito M, et al. An autopsy case of Creutzfeldt-Jakob disease with a prion protein gene codon 180 mutation presenting with pathological laughing and an exaggerated startle reaction. Neuropathology 2017;37: $575-581$. 


\section{Neurology}

\section{Teaching NeuroImages: Cerebral cortex swelling in Creutzfeldt-Jakob disease with V180I mutation}

Atsuhiko Sugiyama, Minako Beppu and Satoshi Kuwabara

Neurology 2018;91;e185-e186

DOI 10.1212/WNL.0000000000005779

\section{This information is current as of July 9, 2018}

\section{Updated Information \& Services}

References

Subspecialty Collections

Permissions \& Licensing

Reprints including high resolution figures, can be found at: http://n.neurology.org/content/91/2/e185.full

This article cites 2 articles, 1 of which you can access for free at: http://n.neurology.org/content/91/2/e185.full\#ref-list-1

This article, along with others on similar topics, appears in the following collection(s):

MRI

http://n.neurology.org/cgi/collection/mri

Prion disease; see Infections/prion

http://n.neurology.org/cgi/collection/prion_disease

Information about reproducing this article in parts (figures,tables) or in its entirety can be found online at:

http://www.neurology.org/about/about_the_journal\#permissions

Information about ordering reprints can be found online:

http://n.neurology.org/subscribers/advertise

Neurology ${ }^{\circledR}$ is the official journal of the American Academy of Neurology. Published continuously since 1951, it is now a weekly with 48 issues per year. Copyright (O) 2018 American Academy of Neurology. All rights reserved. Print ISSN: 0028-3878. Online ISSN: 1526-632X.

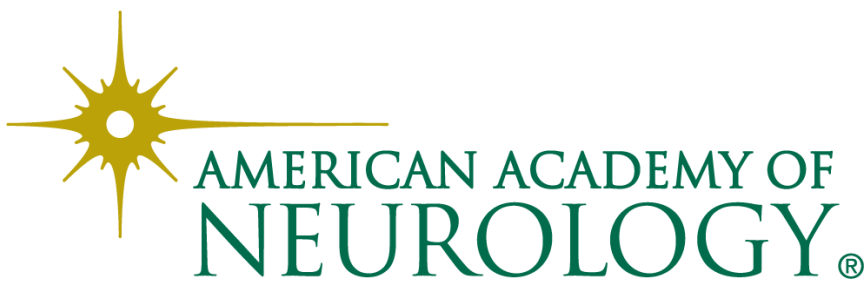

